\title{
Modulation of Telomerase Activity in Cancer Cells by Dietary Compounds: A Review
}

\author{
Takahiro Eitsuka ${ }^{1}{ }^{*}$, Kiyotaka Nakagawa ${ }^{1}$, Shunji Kato ${ }^{1}$, Junya Ito ${ }^{1}$, Yurika Otoki ${ }^{1}$, \\ Soo Takasu ${ }^{1}$, Naoki Shimizu ${ }^{1}$, Takumi Takahashi ${ }^{1}$ and Teruo Miyazawa ${ }^{2,3}$ \\ 1 Food \& Biodynamic Chemistry Laboratory, Graduate School of Agricultural Science, Tohoku University, \\ Sendai 980-0845, Japan; nkgw@m.tohoku.ac.jp (K.N.); tyunkato@gmail.com (S.K.); junyai@tohoku.ac.jp (J.I.); \\ fieldlily.716@gmail.com (Y.O.); soo.takasu@dc.tohoku.ac.jp (S.T.); nshimizu@dc.tohoku.ac.jp (N.S.); \\ t-u.tak@dc.tohoku.ac.jp (T.T.) \\ 2 Food and Biotechnology Innovation Project, New Industry Creation Hatchery Center (NICHe), \\ Tohoku University, Sendai 980-8579, Japan; miyazawa@m.tohoku.ac.jp \\ 3 Food and Health Science Research Unit, Graduate School of Agricultural Science, Tohoku University, \\ Sendai 980-0845, Japan \\ * Correspondence: takahiro.eitsuka.a1@tohoku.ac.jp; Tel.: +81-22-757-4418
}

Received: 31 December 2017; Accepted: 1 February 2018; Published: 6 February 2018

\begin{abstract}
Telomerase is expressed in $\sim 90 \%$ of human cancer cell lines and tumor specimens, whereas its enzymatic activity is not detectable in most human somatic cells, suggesting that telomerase represents a highly attractive target for selective cancer treatment. Accordingly, various classes of telomerase inhibitors have been screened and developed in recent years. We and other researchers have successfully found that some dietary compounds can modulate telomerase activity in cancer cells. Telomerase inhibitors derived from food are subdivided into two groups: one group directly blocks the enzymatic activity of telomerase (e.g., catechin and sulfoquinovosyldiacylglycerol), and the other downregulates the expression of human telomerase reverse transcriptase (hTERT), the catalytic subunit of human telomerase, via signal transduction pathways (e.g., retinoic acid and tocotrienol). In contrast, a few dietary components, including genistein and glycated lipid, induce cellular telomerase activity in several types of cancer cells, suggesting that they may be involved in tumor progression. This review summarizes the current knowledge about the effects of dietary factors on telomerase regulation in cancer cells and discusses their molecular mechanisms of action.
\end{abstract}

Keywords: telomerase; hTERT; cancer; dietary compound

\section{Introduction}

Telomeres cap the ends of linear chromosomes and maintain chromosomal stability by preventing end-to-end fusion and degradation [1]. In mammals, telomeres are composed of 5'-TTAGGG-3' tandem base pair repeats followed by a $3^{\prime}$ G-rich single-stranded overhang. Because conventional DNA polymerases cannot completely replicate the $3^{\prime}$ end of lagging strands owing to the end-replication problem, telomeres shorten by $\sim 50-200$ bases with each round of cell division [2]. Eventually, telomeres reach a critical length and cells enter replicative senescence (the so-called Hayflick limit). Human telomerase, a ribonucleoprotein enzyme, elongates the $3^{\prime}$ end of telomeres by adding the tandem arrays of TTAGGG repeats [3]. Telomerase is expressed in $\sim 90 \%$ of cancer cells and tumor tissues [4], indicating that the addition of telomeric DNA by telomerase contributes to the infinite proliferation of cancer cells. The tumor cells without telomerase activity utilize a unique mechanism of telomere maintenance termed alternative lengthening of telomeres to keep dividing without limits [5]. In most somatic cells, this enzymatic activity is not detectable [4]. Thus, normal cells have a limited 
ability to proliferate. On the other hand, germ cells [6] and self-renewing tissues (e.g., the ovary [4], intestinal epithelium [7], and hematopoietic stem cells [8]) possess telomerase activity.

Human telomerase is essentially composed of two subunits: human telomerase RNA component (hTR; also known as hTERC) and human telomerase reverse transcriptase (hTERT). hTR contains an RNA template complementary to the $3^{\prime}$ overhang of telomeres [9]. hTERT acts as the catalytic subunit that adds telomeric DNA to the $3^{\prime}$ overhang $[10,11]$. Besides, some telomerase-associated proteins such as dyskerin, NOP10, NHP2, and GAR1 have been reported to contribute to proper telomerase function in vivo [12]. Although hTR and telomerase-associated proteins are ubiquitously expressed in all human cells, hTERT is expressed only in telomerase-positive cells and tissues. The expression level of $h T E R T$ mRNA highly correlates with cellular telomerase activity [13], suggesting that hTERT is a critical determinant of telomerase activity. Thus, it is important to understand the mechanism underlying hTERT regulation in order to take advantage of telomerase for cancer diagnosis and treatment.

The $5^{\prime}$ promoter region of $h T E R T$ has been cloned [14-16], and several transcription factors, including c-Myc, Sp1, activating enhancer-binding protein-2 (AP-2), hypoxia-inducible factor 1 (HIF-1), ETS, estrogen receptor (ER), E2F, activator protein 1 (AP-1), vitamin D receptor (VDR) in complex with retinoid $X$ receptor (RXR), p53, Wilms' tumor 1 (WT1), myeloid zinc finger protein 2 (MZF-2), and CCCTC-binding factor (CTCF), have been found to modulate the transcriptional activity of the hTERT promoter (Figure 1) [17]. Among these transcription factors, c-Myc plays a pivotal role in $h T E R T$ mRNA expression. c-Myc can recognize and bind to the E-box consensus sequence ( $5^{\prime}$-CACGTG- $\left.3^{\prime}\right)$ in the target gene promoter. The $h T E R T$ promoter contains two E-box sites located at positions -165 and +44 relative to the transcription start site ( +1 position). The expression of $c-m y c$ mRNA is highly related to the expression of $h T E R T$ mRNA [18]. Treatment with antisense $c-m y c$ oligonucleotides downregulates $c-m y c$ and hTERT expression in human leukemic cells, thus leading to the suppression of cellular telomerase activity [19]. The above findings clearly indicate that c-Myc acts as a crucial signaling factor in the regulation of $h T E R T$ transcription.

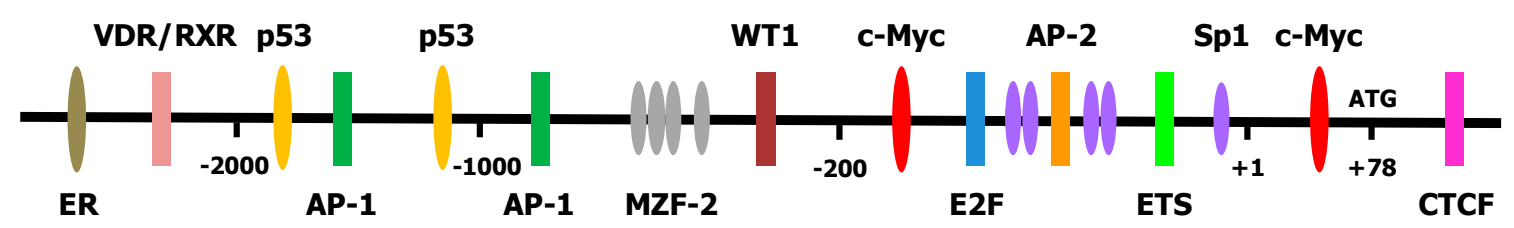

Figure 1. Promoter region of $h T E R T$ and transcription factors essential for regulating its activity. +1 is the transcription start site; +78 (ATG) is the first codon of the hTERT protein.

Epigenetic modifications (i.e., DNA methylation, histone modifications, and noncoding RNA) alter the recruitment of transcription factors and chromatin structure, thereby affecting gene expression [20]. DNA methylation is catalyzed by DNA methyltransferases (DNMTs) through the addition of a methyl group at the C-5 position of cytosine. These enzymes include DNMT1, DNMT3A, and DNMT3B; DNMT1 participates in the methylation of hemimethylated DNA to maintain the methylation status of daughter strands after the replication process, whereas DNMT3A and DNMT3B are responsible for de novo DNA methylation [21]. The cytosine methylation generally occurs in cytosine-guanine (CG) clusters (referred to as $\mathrm{CpG}$ islands). The methyl group in $\mathrm{CpG}$ islands is thought to directly block DNA recognition and binding by several transcription factors, meaning that $\mathrm{CpG}$ methylation is involved in gene silencing. The $h T E R T$ promoter contains many $\mathrm{CpG}$ sites, but most $\mathrm{CpG}$ islands in this promoter are surprisingly hypermethylated (especially from position -650 to -150 relative to the transcription start site) in telomerase-positive cancer cell lines [22]. Such hypermethylation of the $h T E R T$ promoter abrogates binding of transcriptional repressors, such as CTCF and E2F. In fact, treatment of cancer cells with 5-aza-2'-deoxycytidine, a DNA methylation inhibitor, allows CTCF to bind to the $h T E R T$ promoter and to repress $h T E R T$ expression (Figure 2) [23]. Thus, CpG hypermethylation of the $h T E R T$ 
promoter in tumor cells is intended in part to block binding of the transcriptional repressor, thereby increasing the transcription of the $h T E R T$ gene.

Histone modifications such as acetylation, methylation, phosphorylation, and ubiquitination participate in changes of chromatin structure, leading to altered gene transcription [24]. For instance, histone acetylation is mediated by histone acetyltransferases (HATs), which add an acetyl group to a lysine residue within a histone tail. The presence of acetylated lysine in the histone tail attenuates the interaction between histones and DNA, eliciting a relaxed chromatin structure thereby permitting access of transcription factors to the DNA and, therefore, promoting a transcriptionally active gene status. In contrast, histone deacetylases (HDACs) can remove the acetyl group and cause chromatin condensation and gene silencing. Some researchers have shown that trichostatin A (TSA), an HDAC inhibitor, induces $h T E R T$ mRNA expression and telomerase activity in a Mad- and Sp1-dependent manner in normal cells $[25,26]$ but has no effect on cancer cells, such as human fibrosarcoma (HT-1080) and cervical cancer (HeLa and C33A) cell lines. In contrast, $h T E R T$ transcription and telomerase activity are suppressed by treatment with TSA in prostate cancer [27], leukemia [28], and brain cancer cells [29]. Choi et al. [30] revealed that TSA downregulates DNMT1 and causes demethylation of a CTCF-binding site in the $h T E R T$ promoter, resulting in repression of $h T E R T$ expression in HCT116 colorectal cancer cells. These results suggest that the effects of TSA on hTERT transcription depend on cell type. In addition to histone acetylation, $h T E R T$ expression is governed by histone methylation. SET and MYND domain-containing protein 3 (SMYD3) is a lysine 4 on histone 3 (H3K4)-specific dimethyl transferase and trimethyl transferase. SMYD3 binds to a specific DNA sequence ( $5^{\prime}$-CCCTCC- $\left.3^{\prime}\right)$ in the promoter region of $h T E R T$, facilitates dimethylation or trimethylation of $\mathrm{H} 3 \mathrm{~K} 4$, and activates $h T E R T$ transcription [31].

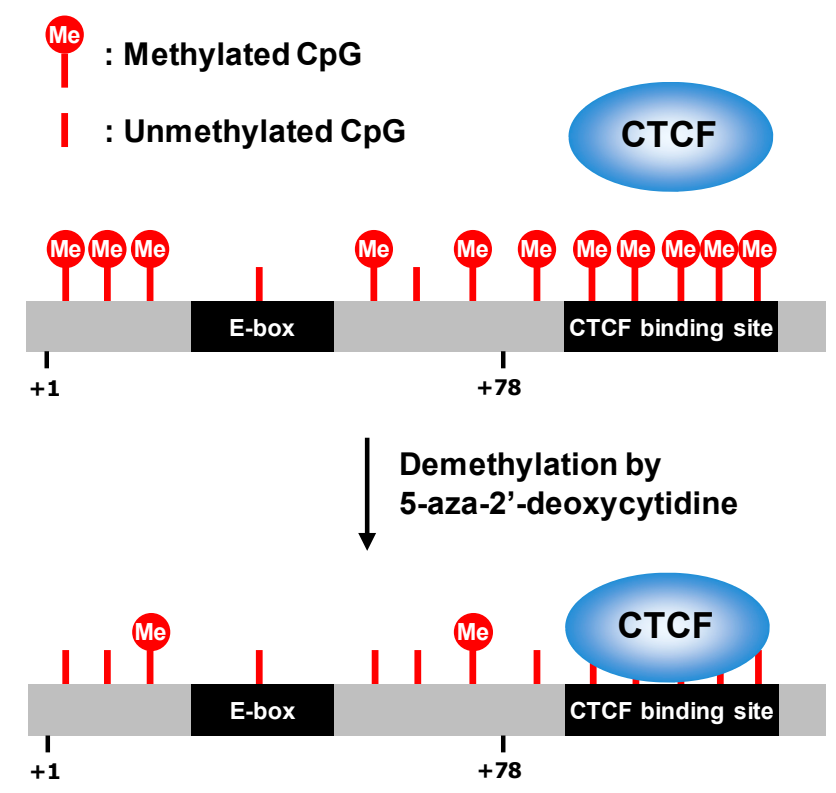

Figure 2. Regulation of $h T E R T$ transcription by 5-aza-2'-deoxycytidine. In cancer cells, CTCF recognition sequence in $h T E R T$ gene is hypermethylated, thus blocking CTCF binding and inducing $h T E R T$ expression. Treatment with 5-aza-2'-deoxycytidine leads to demethylation of $h T E R T$ promoter, thereby causing the binding of CTCF to the target site and suppressing hTERT transcription.

Noncoding RNAs perform key functions in epigenetic regulation. MicroRNAs (miRNAs), one of the largest families of noncoding RNAs, are 23 nucleotides long [32]. They can post-transcriptionally downregulate or degrade their target mRNAs by binding to the recognition sites in the $3^{\prime}$ untranslated region ( $3^{\prime} \mathrm{UTR}$ ) of their specific mRNA, thus acting as repressors of gene expression. Multiple types of miRNAs have been shown to target $h T E R T$ mRNA, thereby reducing proliferation of cells derived 
from neuroblastoma [33], anaplastic thyroid carcinoma [34], gastric cancer [35,36], cervical cancer [37], head and neck squamous cell carcinoma [38], ovarian cancer [39], and breast cancer (Table 1) [40]. These observations indicate that the epigenetic regulation of DNA methylation, histone modifications, and noncoding RNAs markedly contribute to $h T E R T$ gene expression.

Table 1. hTERT regulation by miRNA.

\begin{tabular}{ccc}
\hline Tumor Type & miRNA & Reference \\
\hline Neuroblastoma & miR-138 & {$[33]$} \\
\hline Anaplastic thyroid carcinoma & miR-138 & {$[34]$} \\
\hline \multirow{2}{*}{ Gastric cancer } & miR-1207-5p & {$[35]$} \\
& miR-1266 & {$[35]$} \\
& miR-1182 & {$[36]$} \\
\hline Cervical cancer & miR-491-5p & {$[37]$} \\
\hline Head and neck squamous cell carcinoma & miR-512-5p & {$[38]$} \\
\hline \multirow{2}{*}{ Ovarian cancer } & miR-532 & {$[39]$} \\
& miR-3064 & {$[39]$} \\
\hline \multirow{2}{*}{ Breast cancer } & miR-296 & {$[40]$} \\
& miR-512 & {$[40]$} \\
\hline
\end{tabular}

Telomerase activity in cancer cells is also regulated by promoter mutations and rearrangements of $h T E R T$. Point mutations in the hTERT promoter can generate new consensus motifs for transcription factors [41]. Structural rearrangements of $h T E R T$ bring the enhancers close to the $h T E R T$ promoter [42]. Therefore, mutations and rearrangements of $h T E R T$ participate in the upregulation of hTERT expression.

To date, we and other groups have found that several dietary compounds can regulate telomerase activity in cancer cells. Telomerase inhibitors derived from food are subdivided into two groups: one group interacts with telomerase and directly blocks its enzymatic activity, and the other downregulates the expression of $h T E R T$ via signal transduction pathways. On the other hand, a few dietary components upregulate cellular telomerase activity in several types of cancer cells, implying that they may be involved in tumor progression. This review summarizes the current knowledge about the effects of food factors on telomerase activity in cancer cells and discusses their molecular mechanisms of action.

\section{Inhibition of Telomerase Activity by Dietary Components}

\subsection{Retinoic Acid}

Vitamin A (also known as retinol) is a fat-soluble vitamin necessary for embryonic development, organ formation, immune function, and vision [43]. Retinol is converted to retinal by alcohol dehydrogenase in the body, and retinal can be altered to retinoic acid by retinaldehyde dehydrogenase. Retinoic acid, particularly all-trans retinoic acid (RA; Figure 3A), participates in the regulation of cell growth and differentiation [44]. One in vivo study showed that telomerase activity is reduced during stem cell maturation in embryonic development [45], suggesting that the suppression of telomerase may be linked to cell differentiation. Sharma et al. [46] investigated the effect of differentiation inducers, including dimethyl sulfoxide and RA $(1 \mu \mathrm{M})$, on telomerase activity in HL-60 human leukemia cells, and demonstrated that both inducers decrease this enzymatic activity. These agents do not directly inhibit this activity at all. Furthermore, treatment of SW480 colon carcinoma cells with these inducers does not cause cell differentiation and has no effect on telomerase activity. Love et al. [47] showed that $2 \mu \mathrm{M}$ RA induces differentiation of HL-60 cells and attenuation of $h T E R T$ expression via epigenetic regulation. Treatment with RA leads to hypoacetylation and hypermethylation of the $h T E R T$ promoter by altering DNMT expression. These results $[46,47]$ indicate that telomerase 
inhibition takes place in response to the differentiation status. In contrast, Pendino et al. $[48,49]$ reported that RA can downregulate telomerase independently of cell differentiation. In maturation-resistant NB4 acute promyelocytic leukemia cells, the reduction in telomerase activity by RA stems from the downregulation of $h T E R T$ mRNA expression through activation of retinoic acid receptor (RAR) and RXR [49]. However, $1 \mathrm{nM}$ RA elicits telomerase activity and decreases $\mathrm{p} 16^{\mathrm{INK} 4 \mathrm{~A}}$ expression, therefore extending the lifespan of normal human oral keratinocytes, while $100 \mathrm{nM}$ RA does not influence the cellular senescence [50]. It is noteworthy that the very low concentration of RA ( $1 \mathrm{nM})$ has the characteristic effect on the proliferative capacity of normal keratinocytes.

A<smiles>CC1=C(/C=C(C)/C=C/C=C/C(C)CC(=O)O)C(C)(C)CCC1</smiles>

RA

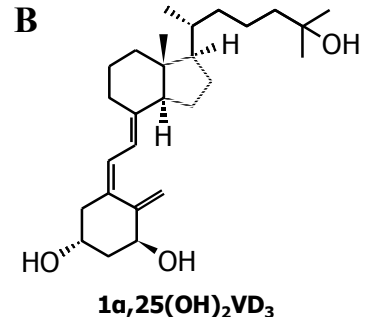

E<smiles>COc1cc(O)c2c(c1)O[C@H](C1C=C(O)C(O)C(O)C1)[C@H](OC(=O)C1CC(O)C(O)C(O)C1)O2</smiles>

F

D

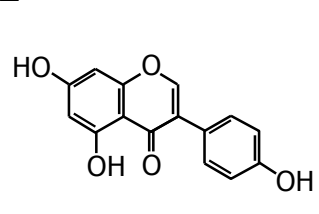

Genistein<smiles>Oc1cccc(C=Cc2cc(O)cc(O)c2)c1</smiles>

Resveratrol<smiles>[R]C(C)NC(CO)[C@H](O)CCCCC</smiles>

H

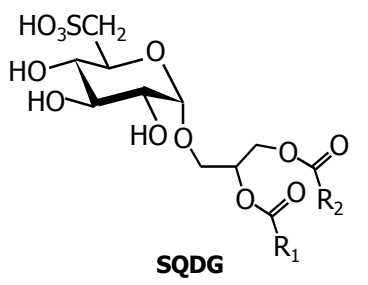

I<smiles>CCCCCCCCCCCCCCCC(=O)O</smiles>

\section{J}<smiles>[R]c1c(C)c2c(c([R])c1O)OC(C)(CCC=C(CCC)CCC=C(C)CCC=C(C)C)O2</smiles><smiles>[R]c1c(C)c2c(c([R])c1O)CCC(C)(CCCC(C)CCCC(C)CCCC(C)C)O2</smiles>

$\mathbf{K}$<smiles>CS(=O)CCCN=C=S</smiles>

Sulforaphane
L

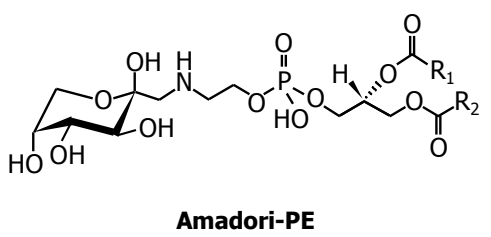

Figure 3. Chemical structures of telomerase modulators. (A) All-trans retinoic acid (RA). (B) 1 $\alpha, 25-\mathrm{Di}$ hydroxy vitamin $\mathrm{D}_{3}\left(1 \alpha, 25(\mathrm{OH})_{2} \mathrm{VD}_{3}\right)$. (C) (-)-Epigallocatechin-3-gallate (EGCG). (D) Curcumin. (E) Genistein. (F) Resveratrol. (G) Ceramide. R, acyl chain. (H) Sulfoquinovosyldiacylglycerol (SQDG). $\mathrm{R}_{1}$ and $\mathrm{R}_{2}$ indicate acyl chains. (I) Eicosapentaenoic acid (EPA). (J) Tocotrienol (T3) and tocopherol (Toc). (K) Sulforaphane. (L) Phosphatidylethanolamine-linked Amadori product (Amadori-PE). $\mathrm{R}_{1}$ and $\mathrm{R}_{2}$ indicate acyl chains. 


\subsection{Vitamin $D_{3}$}

This vitamin is made in the skin from 7-dehydrocholesterol during exposure to ultraviolet sunlight. Vitamin $\mathrm{D}_{3}$ is metabolized by cytochrome P450 (CYP) enzymes such as 27A1 and CYP2R1 in the liver and is then converted to $1 \alpha, 25$-dihydroxyvitamin $\mathrm{D}_{3}\left(1 \alpha, 25(\mathrm{OH})_{2} \mathrm{VD}_{3}\right.$; Figure $\left.3 \mathrm{~B}\right)$, the physiologically active form of vitamin $\mathrm{D}_{3}$, by CYP27B1 in the kidneys [51]. $1 \alpha, 25(\mathrm{OH})_{2} \mathrm{VD}_{3}$ is essential for bone remodeling, immunity, insulin secretion, and blood pressure regulation [52]. In addition to these beneficial effects, $1 \alpha, 25(\mathrm{OH})_{2} \mathrm{VD}_{3}$ acts as a differentiation inducer as well as RA does. Treatment with $1 \alpha, 25(\mathrm{OH})_{2} \mathrm{VD}_{3}$, therefore, drives the differentiation of HL-60 cells and suppresses telomerase activity [46]. Most physiological functions of $1 \alpha, 25(\mathrm{OH})_{2} \mathrm{VD}_{3}$ are mediated by a nuclear transcription factor, VDR [53]. $1 \alpha, 25(\mathrm{OH})_{2} \mathrm{VD}_{3}$ binds to VDR and promotes the interaction with its heterodimer partner, RXR, that is activated by 9-cis-retinoic acid. The VDR-RXR complex binds to a specific DNA sequence called a vitamin D response element (VDRE; there are several versions), initiating the transcription of target genes. Because the promoter region of $h T E R T$ contains a VDRE, Ikeda et al. [54] examined the influence of $1 \alpha, 25(\mathrm{OH})_{2} \mathrm{VD}_{3}$ and 9-cis-retinoic acid on telomerase activity. Although treating PC3 human prostate cancer cells with a single treatment of $1 \alpha, 25(\mathrm{OH})_{2} \mathrm{VD}_{3}$ or 9 -cis-retinoic acid (10 $\mathrm{nM}$ each) did not inhibit telomerase, the combination of $1 \alpha, 25(\mathrm{OH})_{2} \mathrm{VD}_{3}$ and 9-cis-retinoic acid reduced the enzymatic activity via direct interaction of the heterodimer of VDR and RXR with the VDRE. Significant suppression of tumor growth in nude mice inoculated with PC3 cells was observed after intraperitoneal injections of both $1 \alpha, 25(\mathrm{OH})_{2} \mathrm{VD}_{3}(5 \mathrm{ng} /$ mouse $)$ and 9-cis-retinoic acid ( $5 \mathrm{ng} /$ mouse) at 3-day intervals. Kasiappan et al. [55] provided direct evidence for the involvement of a miRNA, miR-498, in the downregulation of $h T E R T$ through VDR. $1 \alpha, 25(\mathrm{OH})_{2} \mathrm{VD}_{3}(100 \mathrm{nM})$ causes the formation of the VDR-RXR heterodimer and its binding to a VDRE located in the $5^{\prime}$ regulatory region of the miR-498 gene in OVCAR3 human ovarian cancer cell line. miR- 498 binds to the complementary sequence in the $3^{\prime} \mathrm{UTR}$ of $h T E R T$ mRNA, thereby leading to its breakdown. These findings imply that VDR plays a unique role in telomerase inhibition by $1 \alpha, 25(\mathrm{OH})_{2} \mathrm{VD}_{3}$.

\subsection{Polyphenols}

These are a major group of phytochemicals present in fruits, vegetables, and beverages, with over 8000 phenolic structures currently identified [56].

The predominant polyphenols in green tea include (-)-epicatechin, (-)-epicatechin-3-gallate, (-)-epigallocatechin, and (-)-epigallocatechin-3-gallate (EGCG; Figure 3C), the last of which accounts for approximately $50 \%$ of the total phenolic content of green tea extract [57]. Naasani et al. [58] revealed that a physiological concentration of catechin $(\sim 1 \mu \mathrm{M})$, particularly EGCG, directly inhibits telomerase activity. An analysis of inhibition kinetics by means of a Dixon plot showed that EGCG is a competitive inhibitor relative to a telomerase substrate primer, indicating that EGCG competitively interacts with the substrate-binding site of telomerase. Prolonged treatment with $15 \mu \mathrm{M}$ EGCG drives telomere shortening in U937 monoblastoid leukemia cells and HT29 adenocarcinoma cells and eventually induces senescence-associated $\beta$-galactosidase activity, a biomarker of cellular aging. Oral administration of EGCG $(1.2 \mathrm{mg} /$ mouse per day) significantly reduces tumor size in nude mice carrying an HCT-L1 (human colon carcinoma cells) xenograft [59]. In addition to direct inhibition of telomerase enzymatic activity, (-)-epigallocatechin and EGCG $(20-40 \mu \mathrm{M})$ repress telomerase via downregulation of $h T E R T$ mRNA [60]. Berletch et al. [61] revealed that $100 \mu \mathrm{M}$ EGCG causes demethylation of $h T E R T$ promoter and binding of E2F-1, an $h T E R T$ repressor, to the target promoter in MCF-7 breast cancer cells. Furthermore, Min et al. [62] showed that the decrease in $h T E R T$ mRNA expression by EGCG in HCT116 human colon cancer cells is driven by increased binding of CTCF to the $h T E R T$ core promoter region via downregulation of DNMT1 expression. Two mechanisms for DNMT inhibition by EGCG have been proposed: EGCG inhibits DNMT activity via direct binding to the catalytic site [63]; alternatively, the suppression of DNMT mRNA expression is implicated in the p21 ${ }^{\mathrm{WAF} 1}$-p300-DNMT axis $[62,64]$. Therefore, the transcriptional repression of $h T E R T$ is primarily due to epigenetic regulation by EGCG. 
Curcumin (Figure 3D) is a major component of turmeric and is commonly consumed as a spice in Asian countries. Curcumin affects several signaling molecules, thus exerting physiological effects such as antioxidant, anti-inflammatory, anticancer, and neuroprotective [65]. Ramachandran et al. [66] revealed that treatment with 50-100 $\mu \mathrm{M}$ curcumin decreases telomerase activity and hTERT mRNA expression in MCF-7 cells but does not influence $c-m y c$ mRNA. This result means that curcumin downregulates telomerase through a c-Myc-independent pathway. Heat shock protein 90 (Hsp90), a molecular chaperone, performs essential functions in the folding and maturation of its substrate proteins, and p23 is a co-chaperone that stabilizes Hsp90-substrate protein complexes. Hsp90 and p23 can bind to hTERT and promote its proper assembly with hTR [67]. Lee and Chung [68] discovered that curcumin disrupts the binding of p23 to hTERT, attenuating nuclear translocation of the hTERT protein and thereby inhibiting telomerase activity. Khaw et al. [69] demonstrated that curcumin prevents telomerase activity and $h T E R T$ expression and found that prolonged treatment (15 days) causes telomere shortening in brain tumor cells.

Genistein (Figure 3E), an isoflavone found abundantly in soy, has protective effects against cancer, obesity, osteoporosis, and inflammation [70]. Some reports have proven that phosphorylation of the hTERT subunit by the Akt kinase [71] and protein kinase C (PKC) [72] augments telomerase activity, indicating that telomerase can be controlled by post-translational modifications. Jagadeesh et al. [73] reported that 10-100 $\mu \mathrm{M}$ genistein reduces telomerase activity in DU-145 and PC-3 prostate cancer cells not only by decreasing $h T E R T$ expression through downregulation of $c-m y c$ but also by dephosphorylation of hTERT through Akt inhibition. Li et al. [74] revealed that treatment of MCF-7 cells with 50-100 $\mu \mathrm{M}$ genistein inhibits DNMT expression and causes hypomethylation of the E2F-1 recognition sequence in the $h T E R T$ promoter, thus leading to increased binding of E2F-1 to its promoter and therefore repressing $h T E R T$ and telomerase activity.

Resveratrol (Figure 3F), which is contained in grapes, red wine, peanuts, and some berries, possesses preventive effects against cancer, cardiovascular diseases, and neurodegenerative disorders [75]. Lanzilli et al. [76] found that resveratrol reduces telomerase activity and the nuclear protein levels of hTERT in MCF-7 cells. Pterostilbene, a dimethyl ether analog of resveratrol, has telomerase-inhibitory properties [77]. Kala et al. [78] showed that a combination of resveratrol $(15 \mu \mathrm{M})$ and pterostilbene $(5 \mu \mathrm{M})$ decreases $h T E R T$ expression through sirtuin 1 (SIRT1) and DNMT inhibition in HCC1806 breast cancer cells. The knockdown of SIRT1, a nicotinamide adenine dinucleotide-dependent deacetylase, represses $h T E R T$ mRNA expression, suggesting the involvement of SIRT1 in $h T E R T$ regulation.

\subsection{Ceramide}

This compound (Figure 3G) consists of sphingosine, a long-chain amino alcohol, linked to a fatty acid via an amide bond, and plays a major part in the metabolism of sphingolipids. Ceramide is used as a substrate to generate more complex sphingolipids (such as sphingomyelin and glycosphingolipids, which are essential components of the cell membrane) while being a degradation product of complex sphingolipid molecules [79]. Ceramide can regulate various cellular phenomena, including cell proliferation, death, migration, and senescence [80]. Inhibitory effects of ceramide on telomerase in A549 human lung adenocarcinoma cells have been extensively investigated by Ogretmen et al. [81-85]. For example, treatment with $20 \mu \mathrm{M}$ C6-ceramide suppresses cellular telomerase activity and causes shortening of telomere length, whereas $20 \mu \mathrm{M}$ dihydro-C6-ceramide shows no inhibition [81,82]. Overexpression of sphingomyelinase, the enzyme responsible for the conversion of sphingomyelin to ceramide, significantly decreases telomerase activity. Moreover, overexpression of glucosylceramide synthase, which converts ceramide to glucosylceramide, attenuates the inhibitory effects of C6-ceramide on telomerase. These findings suggest that telomerase inhibition is specific to ceramide, but not to other sphingolipids. Ceramide represses telomerase activity via decreased hTERT mRNA expression by rapid degradation of the c-Myc protein [83]. Wooten and Ogretmen [84] revealed that downregulation of $h T E R T$ mRNA by ceramide is mediated by Sp1 and Sp3 (transcription 
factors of the Sp1 family)-dependent regulation of $h T E R T$ transcription. Ceramide treatment elicits deacetylation of $\mathrm{Sp} 3$ and histone $\mathrm{H} 3$ at an $h T E R T$ promoter site, thereby preventing the transcription of $h T E R T$ [85].

\subsection{Sulfoquinovosyldiacylglycerol (SQDG)}

The photosynthetic membranes of higher plants contain abundant glyceroglycolipids, including SQDG (Figure 3H), monogalactosyldiacylglycerol (MGDG), and digalactosyldiacylglycerol (DGDG) [86]. SQDG possesses a unique sulfoquinovose headgroup, a derivative of glucose with a sulfonate group, and exerts anticancer effects [87]. We demonstrated that SQDG directly inhibits telomerase activity with 50\% inhibition at $22 \mu \mathrm{M}$, whereas MGDG and DGDG have no effect even at concentrations of $100 \mu \mathrm{M}$ [88]. Eicosapentaenoic acid (EPA), one of SQDG components, inhibits this enzymatic activity too, suggesting that the structure of the sulfate group and fatty acid of SQDG is essential for the inhibitory action on telomerase activity.

\subsection{Fatty Acids}

Fatty acids are a fundamental component of dietary lipids. Among polyunsaturated fatty acids, the n-3 and n- 6 fatty acids are distinguished by the positions of double bonds with respect to the methyl end of the acyl chain. For example, in n-3 fatty acids, the first double bond is located at the third carbon atom from the methyl end. Both n-3 and n-6 fatty acids are important constituents of cell membrane lipids and therefore influence cell membrane properties such as fluidity, flexibility, and membrane-bound enzymatic activities [89]. In addition to the structural functions, n-3 and n-6 fatty acids can act as precursors of bioactive lipid mediators [90]. Long-chain n-3 fatty acids such as EPA (Figure 3I) and docosahexaenoic acid (DHA) have protective effects against inflammation, cancer, cardiovascular disease, and dementia [91]. We found that fatty acids (C18-C22) directly inhibit telomerase activity [92]. IC 50 (the concentration causing 50\% inhibition of the telomerase activity) values are listed in Table 2, indicating that the inhibitory potency of fatty acids increases with the number of double bonds, and that cis-fatty acids possess higher inhibitory activities than trans-isomers do. Accordingly, polyunsaturated fatty acids such as EPA and DHA can strongly prevent telomerase enzymatic activity. A Lineweaver-Burk plot revealed that EPA is a competitive inhibitor relative to the telomerase substrate primer, implying that fatty acids may interact with the primer-binding site of telomerase. Besides, we demonstrated that physiological concentrations of EPA and DHA $(\leq 50 \mu \mathrm{M})$ downregulate $h T E R T$ and $c-m y c$ mRNA via PKC inhibition, thereby repressing telomerase activity. Our results indicate that fatty acids, especially EPA and DHA, not only directly inhibit the enzymatic activity of telomerase but also downregulate telomerase at the transcriptional level.

\subsection{Tocotrienol}

Vitamin E forms can be categorized into two groups: tocopherol (Toc) and tocotrienol (T3), based on their structural difference in the isoprenoid-derived hydrophobic tail (Figure 3J). Both Toc and T3 have four forms: $\alpha-, \beta-, \gamma-$, and $\delta$-isomers. Toc is contained in a variety of foods (e.g., nuts, whole grains, and common vegetable oils). In contrast, T3 is present at low levels in most plants but annatto, palm, and rice bran oils are richer sources of T3 [93]. T3 has a broad range of beneficial activities, including antioxidative, antitumor, antidiabetic, anti-inflammatory, cardioprotective, and neuroprotective properties [94]. These bioactivities of T3 are superior to those of Toc because incorporation of T3 into the lipid bilayer of the cell membrane is more effective than that of Toc [95]. We revealed that 5-20 $\mu \mathrm{M} \mathrm{T3}$, particularly $\beta$ - and $\delta$-isomers, dose-dependently suppresses telomerase activity in DLD-1 human colorectal adenocarcinoma cells, and the inhibitory potency of $\delta$-T3 is stronger than that of the $\beta$-isomer [96]. On the other hand, Toc ( $\alpha-, \beta-, \gamma-$, and $\delta$-isomers) exerts only negligible inhibition of telomerase. The reduction in cellular telomerase activity by T3 is due to downregulation of $h T E R T$ and $c-m y c$ mRNA through PKC inhibition. Furthermore, ferulic acid, a potent phenolic antioxidant 
abundant in rice bran oil, potentiates the anticancer effects of T3 [97]. Co-treatment with T3 and ferulic acid therefore synergistically decrease telomerase and $h T E R T$ expression [98,99].

Table 2. $\mathrm{IC}_{50}$ values of various fatty acids.

\begin{tabular}{|c|c|c|}
\hline Number of Carbon Atoms & Fatty Acid & $\mathrm{IC}_{50}(\mu \mathrm{M})^{1}$ \\
\hline \multirow{2}{*}{$\mathrm{C} 12$} & Lauric acid [12:0] & $>100$ \\
\hline & cis-11-Dodecenoic acid [12:1 $\Delta 11$ cis] & $>100$ \\
\hline \multirow{2}{*}{$\mathrm{C} 14$} & Myristic acid [14:0] & $>100$ \\
\hline & Myristoleic acid [14:1 $\Delta 9$ cis] & $>100$ \\
\hline \multirow[b]{2}{*}{$\mathrm{C} 16$} & Palmitic acid [16:0] & $>100$ \\
\hline & Palmitoleic acid $[16: 1 \Delta 9 c i s]$ & 25 \\
\hline \multirow{9}{*}{$\mathrm{C} 18$} & Stearic acid [18:0] & $>100$ \\
\hline & Oleic acid [18:1 $\Delta 9$ cis] & 35 \\
\hline & Vaccenic acid [18:1 $\Delta 11 c i s]$ & 38 \\
\hline & Elaidic acid [18:1 $\Delta 9$ trans] & 55 \\
\hline & trans-Vaccenic acid [18:1 $\Delta 11$ trans $]$ & 74 \\
\hline & Linoleic acid [18:2 $\Delta 9-12$ cis] & 25 \\
\hline & Linolelaidic acid [18:2 $\Delta 9-12$ trans] & $>50$ \\
\hline & $\gamma$-Linolenic acid [18:3 $\Delta 6-9-12 c i s]$ & 13 \\
\hline & $\alpha$-Linolenic acid [18:2 $\Delta 9-12-15$ cis] & 10 \\
\hline \multirow{9}{*}{$\mathrm{C} 20$} & Arachidic acid [20:0] & $>100$ \\
\hline & cis-5-Eicosenoic acid [20:1 $\Delta 5 \mathrm{cis}]$ & $>100$ \\
\hline & cis-11-Eicosenoic acid [20:1 $\Delta 11$ cis] & $>100$ \\
\hline & trans-11-Eicosenoic acid [20:1 $\Delta 11$ trans] & $>100$ \\
\hline & cis-11-14-Eicosadienoic acid [20:2 $\Delta 11-14 c i s]$ & 70 \\
\hline & cis-8-11-14-Eicosatrienoic acid [20:3 $\Delta 8-11-14 c i s]$ & 30 \\
\hline & cis-11-14-17-Eicosatrienoic acid [20:3 $\Delta 11-14-17$ cis] & 24 \\
\hline & Arachidonic acid [20:4 $\Delta 5-8-11-14 c i s]$ & 25 \\
\hline & Eicosapentaenoic acid (EPA) [20:5 $\Delta 5-8-11-14-17$ cis] & 19 \\
\hline \multirow{2}{*}{$\mathrm{C} 22$} & cis-13-16-19-Docosatrienoic acid [22:3 $\Delta 13-16-19 c i s]$ & 45 \\
\hline & Docosahexaenoic acid (DHA) [22:6 $\Delta 4-7-10-13-16-19 \mathrm{cis}]$ & 5 \\
\hline
\end{tabular}

${ }^{1} \mathrm{IC}_{50}$ : concentration $(\mu \mathrm{M})$ causing $50 \%$ inhibition of telomerase activity.

\subsection{Sulforaphane}

This compound (Figure $3 \mathrm{~K}$ ) is a sulfur-containing isothiocyanate derivative present in cruciferous vegetables such as broccoli, broccoli sprouts, and cauliflower. Sulforaphane exerts powerful anticancer activity via apoptosis induction, suppression of cell cycle progression, angiogenesis inhibition, and anti-inflammatory action [100]. Moon et al. [101] found that 10-20 $\mu \mathrm{M}$ sulforaphane suppresses telomerase activity in Hep3B human hepatoma cells. The reduction in telomerase activity is mediated by downregulation of $h T E R T$ mRNA via c-Myc suppression, as well as dephosphorylation of hTERT through Akt inhibition. Meeran et al. [102] reported that treatment of breast cancer cells (MCF-7 and MDA-MB-231) with sulforaphane causes demethylation of the hTERT promoter via DNMT inhibition, thereby facilitating the binding of CTCF to the promoter site and attenuating $h T E R T$ expression and telomerase activity.

\section{Telomerase Induction in Cancer Cells by Dietary Factors}

\subsection{Genistein}

As described above, genistein in the pharmacological concentration range $(10-100 \mu \mathrm{M})$ reduces telomerase activity. Because physiological concentrations of genistein are estimated to be $<2 \mu \mathrm{M}$, Chau et al. [103] investigated the effect of genistein on telomerase at concentrations of $\leq 1 \mu \mathrm{M}$. As a result, physiologically achievable concentrations of genistein augmented telomerase activity and 
hTERT mRNA expression in DU-145 cells. Of note, TRAMP mice-a popular transgenic mouse model of prostate cancer-fed a diet containing genistein $(250 \mathrm{mg} / \mathrm{kg}$ diet) from 12 to 20 weeks of age demonstrated a threefold increase in prostate weight as compared with the control group. Moreover, significant elevation of telomerase activity was observed in the prostate tissue of TRAMP mice consuming the genistein-supplemented diet. This study raised the possibility that physiological concentrations of genistein may have adverse effects on patients with prostate cancer.

\subsection{A Glycated Lipid}

Maillard reactions may contribute to food deterioration and the pathogenesis of diabetes. Our research group found that phosphatidylethanolamine (PE) reacts with glucose to form a PE-linked Amadori product (Amadori-PE; Figure 3L) [104]. Amadori-PE is present in some foods (e.g., infant formula and chocolate) [105] and, moreover, crucially participates in the development of diabetic complications [106]. Several epidemiological studies have shown that type 2 diabetes significantly raises cancer risk [107]. Nevertheless, little is known about the molecular mechanism underlying the involvement of diabetes in tumor development. We, therefore, examined the link between Amadori-PE and tumor progression, with an emphasis on telomerase activity. Physiological concentrations of Amadori-PE (1-5 $\mu \mathrm{M}$ : plasma concentrations of this lipid in diabetic patients) increased telomerase activity in PANC-1 human pancreatic carcinoma cells by upregulating $h T E R T$ mRNA expression through the induction of $c$-myc [108]. A similar phenomenon was observed in other cancer cells (MIA PaCa-2 human pancreatic carcinoma, HepG2 human hepatoma, and DLD-1). This finding provides experimental evidence for a unique role of lipid glycation in the relation between diabetes and cancer.

\section{Conclusions}

Establishment of the method for the sensitive detection of telomerase activity, namely, the telomeric repeat amplification protocol (TRAP) assay [4], in 1994 enabled screening for telomerase inhibitors, as well as the diagnosis of cancer by means of telomerase. Since then, numerous types of telomerase inhibitors have been identified and developed. Examples of such inhibitors include reverse transcriptase inhibitors (e.g., 3'-azido-3'-deoxythymidine triphosphate [109]), hTR antisense oligonucleotides (e.g., imetelstat [110]), G-quadruplex stabilizers (for instance, TMPyP4 [111]), synthetic compounds from random screening (e.g., BIBR1532 [112]), and HSP90 inhibitors (such as geldanamycin [113]). Among these inhibitors, imetelstat is a potent agent specific to telomerase. Imetelstat can bind with high affinity to hTR, thus blocking the interaction between telomerase and telomere DNA. Recent phase II trials uncovered a clinical benefit of imetelstat for patients with myeloproliferative disorders [114,115].

As mentioned above, several dietary components (i.e., $\mathrm{RA}, 1 \alpha, 25(\mathrm{OH})_{2} \mathrm{VD}_{3}$, polyphenols, ceramide, SQDG, fatty acids, tocotrienol, and sulforaphane) inhibit telomerase by directly blocking the enzymatic activity and/or by decreasing $h T E R T$ expression. Most telomerase inhibitors derived from food factors have been evaluated only in cell culture experiments. To date, a few studies have focused on the in vivo efficacy of these inhibitors [54,59]. Orally administered EGCG suppresses tumor size and shortens telomere length in tumor tissue [59], indicating that EGCG exhibits the telomerase-inhibitory effect in vivo. The in vivo anticancer efficacy of $1 \alpha, 25(\mathrm{OH})_{2} \mathrm{VD}_{3}$ combined with 9-cis-retinoic acid has been examined only by tumor volume measurement [54]. It is unclear whether the tumor suppressive effect of $1 \alpha, 25(\mathrm{OH})_{2} \mathrm{VD}_{3}$ and 9-cis-retinoic acid is mediated through telomerase inhibition since VDR-RXR can affect diverse growth-regulatory signaling pathways [116]. The evaluation of telomerase activity, telomere length, $h T E R T$ expression, or their combination, as well as tumor size measurement, would be necessary to determine the in vivo effectiveness of telomerase inhibitors. In contrast to the chemically synthesized inhibitors such as imetelstat, a human trial targeting telomerase using dietary compounds has never been conducted. A clinical application of dietary factors to cancer treatment is highly attractive because they are nontoxic to healthy cells at physiological concentrations. Prior to initiating human clinical trials, further animal experiments should be performed to investigate 
their potential applications in cancer treatment and prevention. On the other hand, genistein and Amadori-PE induce telomerase activity in cancer cells. Telomerase activity levels in tumor cells positively correlate with an aggressive tumor phenotype [117]. Overexpression of $h T E R T$ induces cell proliferation via upregulation of growth-controlling genes and promotes cell survival by apoptosis suppression $[118,119]$. Therefore, telomerase activation by genistein and Amadori-PE may be relevant to cancer progression.

The TRAP assay is highly sensitive but tends to generate several extra bands, raising the possibility that the potency of telomerase inhibitors may be inappropriately evaluated [120]. However, this assay has been applied by many research groups $[46,55,58,66,73,76,81,101,103]$. Thus, some modified TRAP assays have been reported with improved specificity and reliability [121]. Tatematsu et al. [122] developed a stretch PCR method that achieves quantitative evaluation by the addition of extra tag sequences to the $5^{\prime}$-ends of the forward and reverse PCR primers, and we and some researchers have utilized this method [54,88,92,96,98,108]. On the other hand, treatment with EGCG [58], curcumin [69], and ceramide [82] leads to telomere shortening in cancer cells. Multiple methods have been developed for telomere length analysis, including terminal restriction fragment (TRF) analysis, real-time PCR, single telomere length analysis, and quantitative fluorescence in situ hybridization [123]. Among these methods, TRF analysis is widely used $[58,69,82]$ and is often regarded as the gold standard.

A more detailed understanding of the mechanisms underlying telomerase regulation will be necessary for the identification of novel telomerase inhibitors. Further studies, with special emphasis on in vivo experiments, are needed to apply dietary compounds to cancer treatment and prevention.

Acknowledgments: Some of the work presented in this review was partly supported by a grant from The Tojuro Iijima Foundation for Food Science and Technology, and JSPS KAKENHI Grant Numbers 19780105, 25450185, 17K07803.

Author Contributions: Takahiro Eitsuka wrote the manuscript; Kiyotaka Nakagawa, Shunji Kato, Junya Ito, Yurika Otoki, Soo Takasu, Naoki Shimizu, Takumi Takahashi, and Teruo Miyazawa revised the manuscript.

Conflicts of Interest: The authors declare no conflict of interest.

$\begin{array}{ll}\text { Abbreviations } & \\ \text { hTR } & \text { human telomerase RNA component } \\ \text { hTERT } & \text { human telomerase reverse transcriptase } \\ \text { AP-2 } & \text { activating enhancer-binding protein-2 } \\ \text { HIF-1 } & \text { hypoxia-inducible factor 1 } \\ \text { ER } & \text { estrogen receptor } \\ \text { AP-1 } & \text { activator protein 1 } \\ \text { VDR } & \text { vitamin D receptor } \\ \text { RXR } & \text { retinoid X receptor } \\ \text { WT1 } & \text { Wilms' tumor 1 } \\ \text { MZF-2 } & \text { myeloid zinc finger protein 2 } \\ \text { CTCF } & \text { CCCTC-binding factor } \\ \text { DNMT } & \text { DNA methyltransferase } \\ \text { HAT } & \text { histone acetyltransferase } \\ \text { HDAC } & \text { histone deacetylase } \\ \text { TSA } & \text { trichostatin A } \\ \text { SMYD3 } & \text { SET and MYND domain-containing protein 3 } \\ \text { H3K4 } & \text { lysine 4 on histone 3 } \\ \text { miRNA } & \text { microRNA } \\ 3^{\prime} \text { UTR } & 3^{\prime} \text { untranslated region } \\ \text { RA } & \text { all-trans retinoic acid } \\ \text { RAR } & \text { retinoic acid receptor } \\ \text { CYP } & \text { cytochrome P450 } \\ 1 \alpha, 25(O H)_{2} V_{3} & 1 \alpha, 25-\text { dihydroxyvitamin } D_{3} \\ & \end{array}$




$\begin{array}{ll}\text { VDRE } & \text { vitamin D response element } \\ \text { EGCG } & (- \text {-epigallocatechin-3-gallate } \\ \text { Hsp90 } & \text { heat shock protein } 90 \\ \text { PKC } & \text { protein kinase C } \\ \text { SIRT1 } & \text { sirtuin 1 } \\ \text { SQDG } & \text { Sulfoquinovosyldiacylglycerol } \\ \text { MGDG } & \text { monogalactosyldiacylglycerol } \\ \text { DGDG } & \text { digalactosyldiacylglycerol } \\ \text { EPA } & \text { eicosapentaenoic acid } \\ \text { DHA } & \text { docosahexaenoic acid } \\ \text { Toc } & \text { tocopherol } \\ \text { T3 } & \text { tocotrienol } \\ \text { PE } & \text { phosphatidylethanolamine } \\ \text { Amadori-PE } & \text { phosphatidylethanolamine-linked Amadori product } \\ \text { TRAP } & \text { telomeric repeat amplification protocol }\end{array}$

\section{References}

1. McEachern, M.J.; Krauskopf, A.; Blackburn, E.H. Telomeres and their control. Annu. Rev. Genet. 2000, 34, 331-358. [CrossRef] [PubMed]

2. Levy, M.Z.; Allsopp, R.C.; Futcher, A.B.; Greider, C.W.; Harley, C.B. Telomere end-replication problem and cell aging. J. Mol. Biol. 1992, 225, 951-960. [CrossRef]

3. Morin, G.B. The human telomere terminal transferase enzyme is a ribonucleoprotein that synthesizes TTAGGG repeats. Cell 1989, 59, 521-529. [CrossRef]

4. Kim, N.W.; Piatyszek, M.A.; Prowse, K.R.; Harley, C.B.; West, M.D.; Ho, P.L.; Coviello, G.M.; Wright, W.E.; Weinrich, S.L.; Shay, J.W. Specific association of human telomerase activity with immortal cells and cancers. Science 1994, 266, 2011-2015. [CrossRef] [PubMed]

5. Bryan, T.M.; Englezou, A.; Gupta, J.; Bacchetti, S.; Reddel, R.R. Telomere elongation in immortal human cells without detectable telomerase activity. EMBO J. 1995, 14, 4240-4248. [PubMed]

6. Collins, K.; Mitchell, J.R. Telomerase in the human organism. Oncogene 2002, 21, 564-579. [CrossRef] [PubMed]

7. Hiyama, E.; Tatsumoto, N.; Kodama, T.; Hiyama, K.; Shay, J.; Yokoyama, T. Telomerase activity in human intestine. Int. J. Oncol. 1996, 9, 453-458. [CrossRef] [PubMed]

8. Yui, J.; Chiu, C.P.; Lansdorp, P.M. Telomerase activity in candidate stem cells from fetal liver and adult bone marrow. Blood 1998, 91, 3255-3262. [PubMed]

9. Feng, J.; Funk, W.D.; Wang, S.S.; Weinrich, S.L.; Avilion, A.A.; Chiu, C.P.; Adams, R.R.; Chang, E.; Allsopp, R.C.; Yu, J.; et al. The RNA component of human telomerase. Science 1995, 269, 1236-1241. [CrossRef] [PubMed]

10. Nakamura, T.M.; Morin, G.B.; Chapman, K.B.; Weinrich, S.L.; Andrews, W.H.; Lingner, J.; Harley, C.B.; Cech, T.R. Telomerase catalytic subunit homologs from fission yeast and human. Science 1997, 277, 955-959. [CrossRef] [PubMed]

11. Meyerson, M.; Counter, C.M.; Eaton, E.N.; Ellisen, L.W.; Steiner, P.; Caddle, S.D.; Ziaugra, L.; Beijersbergen, R.L.; Davidoff, M.J.; Liu, Q.; et al. hEST2, the putative human telomerase catalytic subunit gene, is up-regulated in tumor cells and during immortalization. Cell 1997, 90, 785-795. [CrossRef]

12. Arndt, G.M.; MacKenzie, K.L. New prospects for targeting telomerase beyond the telomere. Nat. Rev. Cancer 2016, 16, 508-524. [CrossRef] [PubMed]

13. Takakura, M.; Kyo, S.; Kanaya, T.; Tanaka, M.; Inoue, M. Expression of human telomerase subunits and correlation with telomerase activity in cervical cancer. Cancer Res. 1998, 58, 1558-1561. [PubMed]

14. Cong, Y.S.; Wen, J.; Bacchetti, S. The human telomerase catalytic subunit hTERT: Organization of the gene and characterization of the promoter. Hum. Mol. Genet. 1999, 8, 137-142. [CrossRef]

15. Takakura, M.; Kyo, S.; Kanaya, T.; Hirano, H.; Takeda, J.; Yutsudo, M.; Inoue, M. Cloning of human telomerase catalytic subunit (hTERT) gene promoter and identification of proximal promoter sequences essential for transcriptional activation in immortalized and cancer cells. Cancer Res. 1999, 59, 551-557. [PubMed] 
16. Horikawa, I.; Cable, P.L.; Afshari, C.; Barrett, J.C. Cloning and characterization of the promoter region of human telomerase reverse transcriptase gene. Cancer Res. 1999, 59, 826-830. [PubMed]

17. Kyo, S.; Takakura, M.; Fujiwara, T.; Inoue, M. Understanding and exploiting hTERT promoter regulation for diagnosis and treatment of human cancers. Cancer Sci. 2008, 99, 1528-1538. [CrossRef] [PubMed]

18. Wu, K.J.; Grandori, C.; Amacker, M.; Simon-Vermot, N.; Polack, A.; Lingner, J.; Dalla-Favera, R. Direct activation of TERT transcription by c-MYC. Nat. Genet. 1999, 21, 220-224. [CrossRef] [PubMed]

19. Fujimoto, K.; Takahashi, M. Telomerase activity in human leukemic cell lines is inhibited by antisense pentadecadeoxynucleotides targeted against c-myc mRNA. Biochem. Biophys. Res. Commun. 1997, 241, 775-781. [CrossRef] [PubMed]

20. Egger, G.; Liang, G.; Aparicio, A.; Jones, P.A. Epigenetics in human disease and prospects for epigenetic therapy. Nature 2004, 429, 457-463. [CrossRef] [PubMed]

21. Jair, K.W.; Bachman, K.E.; Suzuki, H.; Ting, A.H.; Rhee, I.; Yen, R.W.; Baylin, S.B.; Schuebel, K.E. De novo CpG island methylation in human cancer cells. Cancer Res. 2006, 66, 682-692. [CrossRef] [PubMed]

22. Zinn, R.L.; Pruitt, K.; Eguchi, S.; Baylin, S.B.; Herman, J.G. hTERT is expressed in cancer cell lines despite promoter DNA methylation by preservation of unmethylated DNA and active chromatin around the transcription start site. Cancer Res. 2007, 67, 194-201. [CrossRef] [PubMed]

23. Renaud, S.; Loukinov, D.; Abdullaev, Z.; Guilleret, I.; Bosman, F.T.; Lobanenkov, V.; Benhattar, J. Dual role of DNA methylation inside and outside of CTCF-binding regions in the transcriptional regulation of the telomerase hTERT gene. Nucleic Acids Res. 2007, 35, 1245-1256. [CrossRef] [PubMed]

24. Jenuwein, T.; Allis, C.D. Translating the histone code. Science 2001, 293, 1074-1080. [CrossRef] [PubMed]

25. Cong, Y.S.; Bacchetti, S. Histone deacetylation is involved in the transcriptional repression of hTERT in normal human cells. J. Biol. Chem. 2000, 275, 35665-35668. [CrossRef] [PubMed]

26. Takakura, M.; Kyo, S.; Sowa, Y.; Wang, Z.; Yatabe, N.; Maida, Y.; Tanaka, M.; Inoue, M. Telomerase activation by histone deacetylase inhibitor in normal cells. Nucleic Acids Res. 2001, 29, 3006-3011. [CrossRef] [PubMed]

27. Suenaga, M.; Soda, H.; Oka, M.; Yamaguchi, A.; Nakatomi, K.; Shiozawa, K.; Kawabata, S.; Kasai, T.; Yamada, Y.; Kamihira, S.; et al. Histone deacetylase inhibitors suppress telomerase reverse transcriptase mRNA expression in prostate cancer cells. Int. J. Cancer 2002, 97, 621-625. [CrossRef] [PubMed]

28. Woo, H.J.; Lee, S.J.; Choi, B.T.; Park, Y.M.; Choi, Y.H. Induction of apoptosis and inhibition of telomerase activity by trichostatin A, a histone deacetylase inhibitor, in human leukemic U937 cells. Exp. Mol. Pathol. 2007, 82, 77-84. [CrossRef] [PubMed]

29. Khaw, A.K.; Silasudjana, M.; Banerjee, B.; Suzuki, M.; Baskar, R.; Hande, M.P. Inhibition of telomerase activity and human telomerase reverse transcriptase gene expression by histone deacetylase inhibitor in human brain cancer cells. Mutat. Res. 2007, 625, 134-144. [CrossRef] [PubMed]

30. Choi, J.H.; Min, N.Y.; Park, J.; Kim, J.H.; Park, S.H.; Ko, Y.J.; Kang, Y.; Moon, Y.J.; Rhee, S.; Ham, S.W.; et al. TSA-induced DNMT1 down-regulation represses hTERT expression via recruiting CTCF into demethylated core promoter region of hTERT in HCT116. Biochem. Biophys. Res. Commun. 2010, 391, 449-454. [CrossRef] [PubMed]

31. Liu, C.; Fang, X.; Ge, Z.; Jalink, M.; Kyo, S.; Björkholm, M.; Gruber, A.; Sjöberg, J.; Xu, D. The telomerase reverse transcriptase (hTERT) gene is a direct target of the histone methyltransferase SMYD3. Cancer Res. 2007, 67, 2626-2631. [CrossRef] [PubMed]

32. Bartel, D.P. MicroRNAs: Target recognition and regulatory functions. Cell 2009, 36, 215-233. [CrossRef] [PubMed]

33. Chakrabarti, M.; Banik, N.L.; Ray, S.K. miR-138 overexpression is more powerful than hTERT knockdown to potentiate apigenin for apoptosis in neuroblastoma in vitro and in vivo. Exp. Cell Res. 2013, 319, 1575-1585. [CrossRef] [PubMed]

34. Mitomo, S.; Maesawa, C.; Ogasawara, S.; Iwaya, T.; Shibazaki, M.; Yashima-Abo, A.; Kotani, K.; Oikawa, H.; Sakurai, E.; Izutsu, N.; et al. Downregulation of miR-138 is associated with overexpression of human telomerase reverse transcriptase protein in human anaplastic thyroid carcinoma cell lines. Cancer Sci. 2008, 99, 280-286. [CrossRef] [PubMed]

35. Chen, L.; Lü, M.H.; Zhang, D.; Hao, N.B.; Fan, Y.H.; Wu, Y.Y.; Wang, S.M.; Xie, R.; Fang, D.C.; Zhang, H.; $\mathrm{Hu}, \mathrm{C} . J . ;$ et al. miR-1207-5p and miR-1266 suppress gastric cancer growth and invasion by targeting telomerase reverse transcriptase. Cell Death Dis. 2014, 5, e1034. [CrossRef] [PubMed] 
36. Zhang, D.; Xiao, Y.F.; Zhang, J.W.; Xie, R.; Hu, C.J.; Tang, B.; Wang, S.M.; Wu, Y.Y.; Hao, N.B.; Yang, S.M. miR-1182 attenuates gastric cancer proliferation and metastasis by targeting the open reading frame of hTERT. Cancer Lett. 2015, 360, 151-159. [CrossRef] [PubMed]

37. Zhao, Q.; Zhai, Y.X.; Liu, H.Q.; Shi, Y.A.; Li, X.B. MicroRNA-491-5p suppresses cervical cancer cell growth by targeting hTERT. Oncol. Rep. 2015, 34, 979-986. [CrossRef] [PubMed]

38. Li, J.; Lei, H.; Xu, Y.; Tao, Z.Z. miR-512-5p suppresses tumor growth by targeting hTERT in telomerase positive head and neck squamous cell carcinoma in vitro and in vivo. PLoS ONE 2015, 10, e0135265. [CrossRef] [PubMed]

39. Bai, L.; Wang, H.; Wang, A.H.; Zhang, L.Y.; Bai, J. MicroRNA-532 and microRNA-3064 inhibit cell proliferation and invasion by acting as direct regulators of human telomerase reverse transcriptase in ovarian cancer. PLoS ONE 2017, 12, e0173912. [CrossRef] [PubMed]

40. Dinami, R.; Buemi, V.; Sestito, R.; Zappone, A.; Ciani, Y.; Mano, M.; Petti, E.; Sacconi, A.; Blandino, G.; Giacca, M.; et al. Epigenetic silencing of miR-296 and miR-512 ensures hTERT dependent apoptosis protection and telomere maintenance in basal-type breast cancer cells. Oncotarget 2017, 8, 95674-95691. [CrossRef] [PubMed]

41. Akincilar, S.C.; Unal, B.; Tergaonkar, V. Reactivation of telomerase in cancer. Cell. Mol. Life Sci. 2016, 73, 1659-1670. [CrossRef] [PubMed]

42. Barthel, F.P.; Wei, W.; Tang, M.; Martinez-Ledesma, E.; Hu, X.; Amin, S.B.; Akdemir, K.C.; Seth, S.; Song, X.; Wang, Q.; et al. Systematic analysis of telomere length and somatic alterations in 31 cancer types. Nat. Genet. 2017, 49, 349-357. [CrossRef] [PubMed]

43. Theodosiou, M.; Laudet, V.; Schubert, M. From carrot to clinic: An overview of the retinoic acid signaling pathway. Cell. Mol. Life Sci. 2010, 67, 1423-1445. [CrossRef] [PubMed]

44. Dragnev, K.H.; Rigas, J.R.; Dmitrovsky, E. The retinoids and cancer prevention mechanisms. Oncologist 2000, 5, 361-368. [CrossRef] [PubMed]

45. Martín-Rivera, L.; Herrera, E.; Albar, J.P.; Blasco, M.A. Expression of mouse telomerase catalytic subunit in embryos and adult tissues. Proc. Natl. Acad. Sci. USA 1998, 95, 10471-10476. [CrossRef] [PubMed]

46. Sharma, H.W.; Sokoloski, J.A.; Perez, J.R.; Maltese, J.Y.; Sartorelli, A.C.; Stein, C.A.; Nichols, G.; Khaled, Z.; Telang, N.T.; Narayanan, R. Differentiation of immortal cells inhibits telomerase activity. Proc. Natl. Acad. Sci. USA 1995, 92, 12343-12346. [CrossRef] [PubMed]

47. Love, W.K.; Berletch, J.B.; Andrews, L.G.; Tollefsbol, T.O. Epigenetic regulation of telomerase in retinoid-induced differentiation of human leukemia cells. Int. J. Oncol. 2008, 32, 625-631. [CrossRef] [PubMed]

48. Pendino, F.; Flexor, M.; Delhommeau, F.; Buet, D.; Lanotte, M.; Segal-Bendirdjian, E. Retinoids down-regulate telomerase and telomere length in a pathway distinct from leukemia cell differentiation. Proc. Natl. Acad. Sci. USA 2001, 98, 6662-6667. [CrossRef] [PubMed]

49. Pendino, F.; Dudognon, C.; Delhommeau, F.; Sahraoui, T.; Flexor, M.; Bennaceur-Griscelli, A.; Lanotte, M.; Ségal-Bendirdjian, E. Retinoic acid receptor alpha and retinoid-X receptor-specific agonists synergistically target telomerase expression and induce tumor cell death. Oncogene 2003, 22, 9142-9150. [CrossRef] [PubMed]

50. You, Y.O.; Lee, G.; Min, B.M. Retinoic acid extends the in vitro life span of normal human oral keratinocytes by decreasing p16(INK4A) expression and maintaining telomerase activity. Biochem. Biophys. Res. Commun. 2000, 268, 268-274. [CrossRef] [PubMed]

51. Bikle, D.D. Vitamin D metabolism, mechanism of action, and clinical applications. Chem. Biol. 2014, 21, 319-329. [CrossRef] [PubMed]

52. Holick, M.F. Vitamin D: Importance in the prevention of cancers, type 1 diabetes, heart disease, and osteoporosis. Am. J. Clin. Nutr. 2004, 79, 362-371. [CrossRef] [PubMed]

53. Sutton, A.L.; MacDonald, P.N. Vitamin D: More than a "bone-a-fide" hormone. Mol. Endocrinol. 2003, 17, 777-791. [CrossRef] [PubMed]

54. Ikeda, N.; Uemura, H.; Ishiguro, H.; Hori, M.; Hosaka, M.; Kyo, S.; Miyamoto, K.; Takeda, E.; Kubota, Y. Combination treatment with 1alpha,25-dihydroxyvitamin D3 and 9-cis-retinoic acid directly inhibits human telomerase reverse transcriptase transcription in prostate cancer cells. Mol. Cancer Ther. 2003, 2, 739-746. [PubMed] 
55. Kasiappan, R.; Shen, Z.; Tse, A.K.; Jinwal, U.; Tang, J.; Lungchukiet, P.; Sun, Y.; Kruk, P.; Nicosia, S.V.; Zhang, X.; et al. 1,25-Dihydroxyvitamin D3 suppresses telomerase expression and human cancer growth through microRNA-498. J. Biol. Chem. 2012, 287, 41297-41309. [CrossRef] [PubMed]

56. Han, X.; Shen, T.; Lou, H. Dietary Polyphenols and Their Biological Significance. Int. J. Mol. Sci. 2007, 8, 950-988. [CrossRef]

57. Lin, J.K.; Liang, Y.C. Cancer chemoprevention by tea polyphenols. Proc. Natl. Sci. Counc. Repub. China B 2000, 24, 1-13. [PubMed]

58. Naasani, I.; Seimiya, H.; Tsuruo, T. Telomerase inhibition, telomere shortening, and senescence of cancer cells by tea catechins. Biochem. Biophys. Res. Commun. 1998, 249, 391-396. [CrossRef] [PubMed]

59. Naasani, I.; Oh-Hashi, F.; Oh-Hara, T.; Feng, W.Y.; Johnston, J.; Chan, K.; Tsuruo, T. Blocking telomerase by dietary polyphenols is a major mechanism for limiting the growth of human cancer cells in vitro and in vivo. Cancer Res. 2003, 63, 824-830. [PubMed]

60. Lin, S.C.; Li, W.C.; Shih, J.W.; Hong, K.F.; Pan, Y.R.; Lin, J.J. The tea polyphenols EGCG and EGC repress mRNA expression of human telomerase reverse transcriptase (hTERT) in carcinoma cells. Cancer Lett. 2006, 236, 80-88. [CrossRef] [PubMed]

61. Berletch, J.B.; Liu, C.; Love, W.K.; Andrews, L.G.; Katiyar, S.K.; Tollefsbol, T.O. Epigenetic and genetic mechanisms contribute to telomerase inhibition by EGCG. J. Cell Biochem. 2008, 103, 509-519. [CrossRef] [PubMed]

62. Min, N.Y.; Kim, J.H.; Choi, J.H.; Liang, W.; Ko, Y.J.; Rhee, S.; Bang, H.; Ham, S.W.; Park, A.J.; Lee, K.H. Selective death of cancer cells by preferential induction of reactive oxygen species in response to (-)-epigallocatechin-3-gallate. Biochem. Biophys. Res. Commun. 2012, 421, 91-97. [CrossRef] [PubMed]

63. Fang, M.Z.; Wang, Y.; Ai, N.; Hou, Z.; Sun, Y.; Lu, H.; Welsh, W.; Yang, C.S. Tea polyphenol (-)-epigallocatechin-3-gallate inhibits DNA methyltransferase and reactivates methylation-silenced genes in cancer cell lines. Cancer Res. 2003, 15, 7563-7570.

64. Tan, H.H.; Porter, A.G. p21WAF1 negatively regulates DNMT1 expression in mammalian cells. Biochem. Biophys. Res. Commun. 2009, 382, 171-176. [CrossRef] [PubMed]

65. Gupta, S.C.; Kismali, G.; Aggarwal, B.B. Curcumin, a component of turmeric: From farm to pharmacy. Biofactors 2013, 39, 2-13. [CrossRef] [PubMed]

66. Ramachandran, C.; Fonseca, H.B.; Jhabvala, P.; Escalon, E.A.; Melnick, S.J. Curcumin inhibits telomerase activity through human telomerase reverse transcritpase in MCF-7 breast cancer cell line. Cancer Lett. 2002, 184, 1-6. [CrossRef]

67. Forsythe, H.L.; Jarvis, J.L.; Turner, J.W.; Elmore, L.W.; Holt, S.E. Stable association of hsp90 and p23, but Not hsp70, with active human telomerase. J. Biol. Chem. 2001, 276, 15571-15574. [CrossRef] [PubMed]

68. Lee, J.H.; Chung, I.K. Curcumin inhibits nuclear localization of telomerase by dissociating the Hsp90 co-chaperone p23 from hTERT. Cancer Lett. 2010, 290, 76-86. [CrossRef] [PubMed]

69. Khaw, A.K.; Hande, M.P.; Kalthur, G.; Hande, M.P. Curcumin inhibits telomerase and induces telomere shortening and apoptosis in brain tumour cells. J. Cell Biochem. 2013, 114, 1257-1270. [CrossRef] [PubMed]

70. Mukund, V.; Mukund, D.; Sharma, V.; Mannarapu, M.; Alam, A. Genistein: Its role in metabolic diseases and cancer. Crit. Rev. Oncol. Hematol. 2017, 119, 13-22.

71. Kang, S.S.; Kwon, T.; Kwon, D.Y.; Do, S.I. Akt protein kinase enhances human telomerase activity through phosphorylation of telomerase reverse transcriptase subunit. J. Biol. Chem. 1999, 274, 13085-13090. [CrossRef] [PubMed]

72. Kim, Y.W.; Hur, S.Y.; Kim, T.E.; Lee, J.M.; Namkoong, S.E.; Ki, I.K.; Kim, J.W. Protein kinase C modulates telomerase activity in human cervical cancer cells. Exp. Mol. Med. 2001, 33, 156-163. [CrossRef] [PubMed]

73. Jagadeesh, S.; Kyo, S.; Banerjee, P.P. Genistein represses telomerase activity via both transcriptional and posttranslational mechanisms in human prostate cancer cells. Cancer Res. 2006, 66, 2107-2115. [CrossRef] [PubMed]

74. Li, Y.; Liu, L.; Andrews, L.G.; Tollefsbol, T.O. Genistein depletes telomerase activity through cross-talk between genetic and epigenetic mechanisms. Int. J. Cancer 2009, 125, 286-296. [CrossRef] [PubMed]

75. Rauf, A.; Imran, M.; Suleria, H.A.R.; Ahmad, B.; Peters, D.G.; Mubarak, M.S. A comprehensive review of the health perspectives of resveratrol. Food Funct. 2017, 8, 4284-4305. [CrossRef] [PubMed] 
76. Lanzilli, G.; Fuggetta, M.P.; Tricarico, M.; Cottarelli, A.; Serafino, A.; Falchetti, R.; Ravagnan, G.; Turriziani, M.; Adamo, R.; Franzese, O.; et al. Resveratrol down-regulates the growth and telomerase activity of breast cancer cells in vitro. Int. J. Oncol. 2006, 28, 641-648. [CrossRef] [PubMed]

77. Tippani, R.; Prakhya, L.J.; Porika, M.; Sirisha, K.; Abbagani, S.; Thammidala, C. Pterostilbene as a potential novel telomerase inhibitor: Molecular docking studies and its in vitro evaluation. Curr. Pharm. Biotechnol. 2014, 14, 1027-1035. [CrossRef] [PubMed]

78. Kala, R.; Shah, H.N.; Martin, S.L.; Tollefsbol, T.O. Epigenetic-based combinatorial resveratrol and pterostilbene alters DNA damage response by affecting SIRT1 and DNMT enzyme expression, including SIRT1-dependent $\gamma$-H2AX and telomerase regulation in triple-negative breast cancer. BMC Cancer 2015, 15, 672. [CrossRef] [PubMed]

79. Ogretmen, B.; Hannun, Y.A. Biologically active sphingolipids in cancer pathogenesis and treatment. Nat. Rev. Cancer. 2004, 4, 604-616. [CrossRef] [PubMed]

80. Saddoughi, S.A.; Ogretmen, B. Diverse functions of ceramide in cancer cell death and proliferation. Adv. Cancer Res. 2013, 117, 37-58. [PubMed]

81. Ogretmen, B.; Schady, D.; Usta, J.; Wood, R.; Kraveka, J.M.; Luberto, C.; Birbes, H.; Hannun, Y.A.; Obeid, L.M. Role of ceramide in mediating the inhibition of telomerase activity in A549 human lung adenocarcinoma cells. J. Biol. Chem. 2001, 276, 24901-24910. [CrossRef] [PubMed]

82. Sundararaj, K.P.; Wood, R.E.; Ponnusamy, S.; Salas, A.M.; Szulc, Z.; Bielawska, A.; Obeid, L.M.; Hannun, Y.A.; Ogretmen, B. Rapid shortening of telomere length in response to ceramide involves the inhibition of telomere binding activity of nuclear glyceraldehyde-3-phosphate dehydrogenase. J. Biol. Chem. 2004, 279, 6152-6162. [CrossRef] [PubMed]

83. Ogretmen, B.; Kraveka, J.M.; Schady, D.; Usta, J.; Hannun, Y.A.; Obeid, L.M. Molecular mechanisms of ceramide-mediated telomerase inhibition in the A549 human lung adenocarcinoma cell line. J. Biol. Chem. 2001, 276, 32506-32514. [CrossRef] [PubMed]

84. Wooten, L.G.; Ogretmen, B. Sp1/Sp3-dependent regulation of human telomerase reverse transcriptase promoter activity by the bioactive sphingolipid ceramide. J. Biol. Chem. 2005, 280, 28867-28876. [CrossRef] [PubMed]

85. Wooten-Blanks, L.G.; Song, P.; Senkal, C.E.; Ogretmen, B. Mechanisms of ceramide-mediated repression of the human telomerase reverse transcriptase promoter via deacetylation of Sp3 by histone deacetylase 1. FASEB J. 2007, 21, 3386-3397. [CrossRef] [PubMed]

86. Bishop, D.G.; Sparace, S.A.; Mudd, J.B. Biosynthesis of sulfoquinovosyldiacylglycerol in higher plants: The origin of the diacylglycerol moiety. Arch. Biochem. Biophys. 1985, 240, 851-858. [CrossRef]

87. Sahara, H.; Ishikawa, M.; Takahashi, N.; Ohtani, S.; Sato, N.; Gasa, S.; Akino, T.; Kikuchi, K. In vivo anti-tumour effect of $3^{\prime}$-sulphonoquinovosyl $1^{\prime}$-monoacylglyceride isolated from sea urchin (Strongylocentrotus intermedius) intestine. Br. J. Cancer. 1997, 75, 324-332. [CrossRef] [PubMed]

88. Eitsuka, T.; Nakagawa, K.; Igarashi, M.; Miyazawa, T. Telomerase inhibition by sulfoquinovosyldiacylglycerol from edible purple laver (Porphyra yezoensis). Cancer Lett. 2004, 212, 15-20. [CrossRef] [PubMed]

89. Stillwell, W.; Wassall, S.R. Docosahexaenoic acid: Membrane properties of a unique fatty acid. Chem. Phys. Lipids 2003, 126, 1-27. [CrossRef]

90. Bannenberg, G.; Serhan, C.N. Specialized pro-resolving lipid mediators in the inflammatory response: An update. Biochim. Biophys. Acta 2010, 1801, 1260-1273. [CrossRef] [PubMed]

91. Sampath, H.; Ntambi, J.M. Polyunsaturated fatty acid regulation of gene expression. Nutr. Rev. 2004, 62, 333-339. [CrossRef] [PubMed]

92. Eitsuka, T.; Nakagawa, K.; Suzuki, T.; Miyazawa, T. Polyunsaturated fatty acids inhibit telomerase activity in DLD-1 human colorectal adenocarcinoma cells: A dual mechanism approach. Biochim. Biophys. Acta 2005, 1737, 1-10. [CrossRef] [PubMed]

93. Packer, L.; Weber, S.U.; Rimbach, G. Molecular aspects of alpha-tocotrienol antioxidant action and cell signalling. J. Nutr. 2001, 131, 369S-373S. [CrossRef] [PubMed]

94. Aggarwal, B.B.; Sundaram, C.; Prasad, S.; Kannappan, R. Tocotrienols, the vitamin E of the 21st century: Its potential against cancer and other chronic diseases. Biochem. Pharmacol. 2010, 80, 1613-1631. [CrossRef] [PubMed] 
95. Suzuki, Y.J.; Tsuchiya, M.; Wassall, S.R.; Choo, Y.M.; Govil, G.; Kagan, V.E.; Packer, L. Structural and dynamic membrane properties of alpha-tocopherol and alpha-tocotrienol: Implication to the molecular mechanism of their antioxidant potency. Biochemistry 1993, 32, 10692-10699. [CrossRef] [PubMed]

96. Eitsuka, T.; Nakagawa, K.; Miyazawa, T. Down-regulation of telomerase activity in DLD-1 human colorectal adenocarcinoma cells by tocotrienol. Biochem. Biophys. Res. Commun. 2006, 348, 170-175. [CrossRef] [PubMed]

97. Eitsuka, T.; Tatewaki, N.; Nishida, H.; Kurata, T.; Nakagawa, K.; Miyazawa, T. Synergistic inhibition of cancer cell proliferation with a combination of $\delta$-tocotrienol and ferulic acid. Biochem. Biophys. Res. Commun. 2014, 453, 606-611. [CrossRef] [PubMed]

98. Eitsuka, T.; Tatewaki, N.; Nishida, H.; Nakagawa, K.; Miyazawa, T. A combination of $\delta$-tocotrienol and ferulic acid synergistically inhibits telomerase activity in DLD-1 human colorectal adenocarcinoma cells. J. Nutr. Sci. Vitaminol. 2016, 62, 281-287. [CrossRef] [PubMed]

99. Eitsuka, T.; Tatewaki, N.; Nishida, H.; Nakagawa, K.; Miyazawa, T. Synergistic Anticancer Effect of Tocotrienol Combined with Chemotherapeutic Agents or Dietary Components: A Review. Int. J. Mol. Sci. 2016, 17, 1605. [CrossRef] [PubMed]

100. Juge, N.; Mithen, R.F.; Traka, M. Molecular basis for chemoprevention by sulforaphane: A comprehensive review. Cell Mol. Life Sci. 2007, 64, 1105-1127. [CrossRef] [PubMed]

101. Moon, D.O.; Kang, S.H.; Kim, K.C.; Kim, M.O.; Choi, Y.H.; Kim, G.Y. Sulforaphane decreases viability and telomerase activity in hepatocellular carcinoma Hep3B cells through the reactive oxygen species-dependent pathway. Cancer Lett. 2010, 295, 260-266. [CrossRef] [PubMed]

102. Meeran, S.M.; Patel, S.N.; Tollefsbol, T.O. Sulforaphane causes epigenetic repression of hTERT expression in human breast cancer cell lines. PLoS ONE 2010, 5, e11457. [CrossRef] [PubMed]

103. Chau, M.N.; El Touny, L.H.; Jagadeesh, S.; Banerjee, PP. Physiologically achievable concentrations of genistein enhance telomerase activity in prostate cancer cells via the activation of STAT3. Carcinogenesis 2007, 28, 2282-2290. [CrossRef] [PubMed]

104. Oak, J.H.; Nakagawa, K.; Miyazawa, T. Synthetically prepared Aamadori-glycated phosphatidylethanolaminecan trigger lipid peroxidation via free radical reactions. FEBS Lett. 2000, 481, 26-30. [CrossRef]

105. Oak, J.H.; Nakagawa, K.; Miyazawa, T. UV analysis of Amadori-glycated phosphatidylethanolamine in foods and biological samples. J. Lipid Res. 2002, 43, 523-529. [PubMed]

106. Nakagawa, K.; Oak, J.H.; Higuchi, O.; Tsuzuki, T.; Oikawa, S.; Otani, H.; Mune, M.; Cai, H.; Miyazawa, T. Ion-trap tandem mass spectrometric analysis of Amadori-glycated phosphatidylethanolamine in human plasma with or without diabetes. J. Lipid Res. 2005, 46, 2514-2524. [CrossRef] [PubMed]

107. Everhart, J.; Wright, D. Diabetes mellitus as a risk factor for pancreatic cancer. A meta-analysis. JAMA 1995, 273, 1605-1609. [CrossRef] [PubMed]

108. Eitsuka, T.; Nakagawa, K.; Ono, Y.; Tatewaki, N.; Nishida, H.; Kurata, T.; Shoji, N.; Miyazawa, T. Amadori-glycated phosphatidylethanolamine up-regulates telomerase activity in PANC-1 human pancreatic carcinoma cells. FEBS Lett. 2012, 586, 2542-2547. [CrossRef] [PubMed]

109. Pai, R.B.; Pai, S.B.; Kukhanova, M.; Dutschman, G.E.; Guo, X.; Cheng, Y.C. Telomerase from human leukemia cells: Properties and its interaction with deoxynucleoside analogues. Cancer Res. 1998, 58, 1909-1913. [PubMed]

110. Jackson, S.R.; Zhu, C.H.; Paulson, V.; Watkins, L.; Dikmen, Z.G.; Gryaznov, S.M.; Wright, W.E.; Shay, J.W. Antiadhesive effects of GRN163L-an oligonucleotide N3'->P5' thio-phosphoramidate targeting telomerase. Cancer Res. 2007, 67, 1121-1129. [CrossRef] [PubMed]

111. Wheelhouse, R.T.; Sun, D.; Han, H.; Han, F.X.; Hurley, L.H. Cationic porphyrins as telomerase inhibitors: The interaction of tetra-(N-methyl-4-pyridyl)porphine with quadruplex DNA. J. Am. Chem. Soc. 1998, 120, 3261-3262. [CrossRef]

112. Damm, K.; Hemmann, U.; Garin-Chesa, P.; Hauel, N.; Kauffmann, I.; Priepke, H.; Niestroj, C.; Daiber, C.; Enenkel, B.; Guilliard, B.; et al. A highly selective telomerase inhibitor limiting human cancer cell proliferation. EMBO J. 2001, 20, 6958-6968. [CrossRef] [PubMed]

113. Villa, R.; Folini, M.; Porta, C.D.; Valentini, A.; Pennati, M.; Daidone, M.G.; Zaffaroni, N. Inhibition of telomerase activity by geldanamycin and 17-allylamino, 17-demethoxygeldanamycin in human melanoma cells. Carcinogenesis 2003, 24, 851-859. [CrossRef] [PubMed] 
114. Tefferi, A.; Lasho, T.L.; Begna, K.H.; Patnaik, M.M.; Zblewski, D.L.; Finke, C.M.; Laborde, R.R.; Wassie, E.; Schimek, L.; Hanson, C.A.; et al. A Pilot Study of the Telomerase Inhibitor Imetelstat for Myelofibrosis. N. Engl. J. Med. 2015, 373, 908-919. [CrossRef] [PubMed]

115. Baerlocher, G.M.; Oppliger Leibundgut, E.; Ottmann, O.G.; Spitzer, G.; Odenike, O.; McDevitt, M.A.; Röth, A.; Daskalakis, M.; Burington, B.; Stuart, M.; et al. Telomerase Inhibitor Imetelstat in Patients with Essential Thrombocythemia. N. Engl. J. Med. 2015, 373, 920-928. [CrossRef] [PubMed]

116. Campbell, F.C.; Xu, H.; El-Tanani, M.; Crowe, P.; Bingham, V. The yin and yang of vitamin D receptor (VDR) signaling in neoplastic progression: Operational networks and tissue-specific growth control. Biochem. Pharmacol. 2010, 79, 1-9. [CrossRef] [PubMed]

117. Hiyama, E.; Hiyama, K.; Yokoyama, T.; Matsuura, Y.; Piatyszek, M.A.; Shay, J.W. Correlating telomerase activity levels with human neuroblastoma outcomes. Nat. Med. 1995, 1, 249-255. [CrossRef] [PubMed]

118. Smith, L.L.; Coller, H.A.; Roberts, J.M. Telomerase modulates expression of growth-controlling genes and enhances cell proliferation. Nat. Cell Biol. 2003, 5, 474-479. [CrossRef] [PubMed]

119. Gorbunova, V.; Seluanov, A.; Pereira-Smith, O.M. Expression of human telomerase (hTERT) does not prevent stress-induced senescence in normal human fibroblasts but protects the cells from stress-induced apoptosis and necrosis. J. Biol. Chem. 2002, 277, 38540-38549. [CrossRef] [PubMed]

120. Maritz, M.F.; Richards, L.A.; Mackenzie, K.L. Assessment and quantification of telomerase enzyme activity. Methods Mol. Biol. 2013, 965, 215-231. [PubMed]

121. Fajkus, J. Detection of telomerase activity by the TRAP assay and its variants and alternatives. Clin. Chim. Acta 2006, 371, 25-31. [CrossRef] [PubMed]

122. Tatematsu, K.; Nakayama, J.; Danbara, M.; Shionoya, S.; Sato, H.; Omine, M.; Ishikawa, F. A novel quantitative 'stretch PCR assay', that detects a dramatic increase in telomerase activity during the progression of myeloid leukemias. Oncogene 1996, 13, 2265-2274. [PubMed]

123. Montpetit, A.J.; Alhareeri, A.A.; Montpetit, M.; Starkweather, A.R.; Elmore, L.W.; Filler, K.; Mohanraj, L.; Burton, C.W.; Menzies, V.S.; Lyon, D.E.; et al. Telomere length: A review of methods for measurement. Nurs. Res. 2014, 63, 289-299. [CrossRef] [PubMed] 